\title{
The Subversive Humphry Davy: Aristocracy and Establishing Chemical Research Laboratories in Late Eighteenth- and Early Nineteenth-Century England
}

\author{
Frank A.J.L. James
}

As other essays in this volume testify, chemistry, in all its multifarious guises throughout Europe, could be undertaken within a wide range of institutional, organisational and physical settings. This essay discusses the beginnings in England at the end of the eighteenth century of one type of setting, namely institutional laboratories funded by subscription that were either envisioned or came to be devoted to chemical research. Such laboratories required a number of material things before they could start to produce scientific knowledge: a building, building services (heating, lighting, water, and so on) and apparatus. Furthermore, appropriately trained staff including researchers, laboratory assistants and servants, also needed to be found. Less tangibly, it was important to have available retrievable recording methods and some access to disseminating the knowledge produced. These components did not appear of their own volition, but required substantial financial support, to be organized and governed, all through human agency. Even today none of this is straightforward, but when no appropriate models were available that could be followed to achieve the desired aims, the difficulties became manifold. Inevitably under such circumstances, a strong tendency existed to underdefine and underspecify what a laboratory required, particularly in terms of management, and to start with the familiar. That left ample scope for unintended consequences, the idiosyncrasies of individual agency and the subversion of original aims.

This essay explores these themes through examining the founding and development of the first two subscription funded research laboratories in England, located in the Medical Pneumatic Institution (MPI) in Bristol and the Royal Institution of Great Britain (RIGB) in London, both established in the late 1790s. This is not to suggest that research laboratories did not previously exist in Great Britain. Two of the most significant were funded privately by individual wealthy aristocrats, one in Clapham, Surrey, built by and for Henry Cavendish (1731-1810) and the other by the Second Earl of Shelburne (1737-

(C) FRANK A.J.L. JAMES, 2018 | DOI 10.1163/9789004325562_013

This is an open access chapter distributed under the terms of the CC-BY-NC License. 
1805) at his Bowood seat in Wiltshire where Joseph Priestley (1733-1804) and Jan Ingen-Housz (1730-1799) worked. ${ }^{1}$ Both laboratories were entirely dependent on aristocratic interest and whim, with no mechanism for them to be sustained beyond their patrons' lives. It is perhaps no coincidence that much of Cavendish's apparatus later wound up at the RIGB, where he was a leading figure during its early years. ${ }^{2}$

It might be assumed a priori that subscription-funded laboratories would be organized differently from those supported aristocratically and command longer term support, since their funding base was broader and seemingly not dependent on any specific individual. In practice, it had to be learned how such novel organisations should be managed. That meant, to some extent at least, beginning with familiar organisational methods, thus potentially subjecting the new institutions to the same issues surrounding individual domination, continuity and legacy that arose with aristocratic patronage. Aristocratic laboratories provided one of the few models available in Great Britain about how a research laboratory might be managed; furthermore, a large proportion of subscriptions for both the MPI and RIGB came from aristocrats. These new laboratories were not ex nihilo creations, linked distinctively, according to some accounts, to notions of increasing industrialization or a rising middle class, but were also closely connected to the traditional British ruling class whose power was still enormous.

The MPI and the RIGB were also linked together closely by a single individual, Humphry Davy (1778-1829). He was the former's superintendent for nearly two and a half years from October 1798 until March 1801, when he moved to the latter. While the considerable literatures on Davy, the MPI and the RIGB do, of course, note the connection, its significance for the development of research

1 Christa Jungnickel and Russell McCormmach, Cavendish: The experimental life ([Lewisburg]: Bucknell, 1998), 329-30. Robert E. Schofield, The Enlightened Joseph Priestley: A study of his life and work from 1773 to 1804 (University Park: Pennsylvania State University Press, 2004), 3-143; Norman Beale and Elaine Beale, Echoes of Ingen Housz: The long lost story of the genius who rescued the Habsburgs from smallpox and became the father of photosynthesis (East Knoyle: Hobnob Press, 2011).

2 The minutes of the meetings of the Royal Institution's Managers are in RI MS AD/2/B/2/A followed by volume number. This will be cited here as RI MM followed by date of meeting, volume and page numbers. The minutes of nineteenth-century meetings were published in facsimile as Archives of the Royal Institution, Minutes of the Managers' Meetings, 1799-1903, 15 volumes in 7 (London: Scholar Press, 1971-1976). Cavendish's apparatus is referred to in RI MM, 9 July 1810, 5: 126 . 
laboratories in Great Britain has not really been appreciated. ${ }^{3}$ This essay argues that Davy's unique career trajectory from provincial obscurity in Penzance, in the far west of England, to the MPI, provided him with the skills, experience and commitment to negotiate and persuade the RIGB to add research to its activities, something that had never been intended or even envisaged by its founders. Davy brought about this significant transformation in a manner reminiscent of the way aristocratic laboratories were organized. As a consequence he established at the RIGB what became for much of the nineteenth century the best-equipped chemical and natural philosophical research laboratory in England. Many fundamental discoveries would be made there by Davy and his successors, such as Michael Faraday (1791-1867), John Tyndall (c.1822-1893) and James Dewar (1842-1923). ${ }^{4}$ Their successes contributed to ensuring that the RIGB came to serve as a model, or at least a starting point, for the organisation of science in other places, most notably the Smithsonian Institution in Washington in $1846 .^{5}$

\section{The Medical Pneumatic Institution}

The MPI stemmed from the work of Thomas Beddoes (1760-1808), the son of a reasonably wealthy tanner with significant land holdings in Shifnal, Shrop-

3 June Fullmer, Young Humphry Davy: The making of an experimental chemist (Philadelphia: American Philosophical Society, 200o); David Knight, Humphry Davy: Science and power (Oxford: Blackwell, 1992; Second Edition, Cambridge: Cambridge University Press, 1996); Sophie Forgan, ed., Science and the Sons of Genius: Studies on Humphry Dary (London: Science Reviews, 1980); Trevor H. Levere, "Dr. Thomas Beddoes and the Establishment of His Pneumatic Institution: A tale of three presidents," Notes and Records of the Royal Society of London 32 (1977): 41-9; Mike Jay, The Atmosphere of Heaven:The unnatural experiments of Dr. Beddoes and his sons of genius (New Haven: Yale University Press, 2009); Henry Bence Jones, The Royal Institution: Its founders, and its first professors (London: Longman, 1871); Morris Berman, Social Change and Scientific Organization: The Royal Institution, 1799-1844 (Ithaca: Cornell University Press, 1978); Frank A.J.L. James, ed., 'The Common Purposes of Life': Science and society at the Royal Institution of Great Britain (Aldershot: Ashgate, 2002).

4 Frank A.J.L.James, Michael Faraday: A very short introduction (Oxford: Oxford University Press, 2010); Roland Jackson, "John Tyndall and the Early History of Diamagnetism," Annals of Science 72 (2015): 435-89; John Rowlinson, Sir James Dewar, 1842-1923: A ruthless chemist (Farnham: Ashgate, 2012).

5 Heather Ewing, The Lost World of James Smithson: Science, revolution, and the birth of the Smithsonian (New York: Bloomsbury, 2007). 
shire. ${ }^{6}$ He attended Pembroke College, Oxford, before studying chemistry with Bryan Higgins (c.1741-1818) in London and then with Joseph Black (1728-1799) at Edinburgh University. Returning to Oxford in 1786 , he took his MD, followed by a visit to France. There he became acquainted with many leading chemists, including Antoine Lavoisier (1743-1794), following which he adopted the new chemical nomenclature. From 1787 until his final lecture series delivered in the spring of 1792, he held the non-stipendiary Readership in Chemistry at Oxford University. He then resigned following disagreements in Oxford centering on his support for the French Revolution and his general position as a democrat, which led him to be subjected to government harassment. ${ }^{7}$

Needing an income, Beddoes decided to practice medicine and by early April 1793 had acquired the lease on 11 Hope Square, Hotwells. ${ }^{8}$ Located near Bristol, the fifth largest city in England, Hotwells, a small spa village on the banks of the river Avon across from Somerset, had a long tradition of wealthy and aristocratic visitors coming to take the waters to benefit their health since the seventeenth century. ${ }^{9}$ The Midlands engineer and industrialist James Watt sr. (1736-1819) had no doubt that Beddoes chose Bristol "for the greater [medical] practice," suggesting he believed that the choice of location was entirely deliberate, enabling Beddoes to be near wealth and potential patronage. ${ }^{10}$

Furthermore, Bristol was also geographically convenient for Bowood, and evidence suggests that Beddoes had links there, especially with Ingen-Housz. ${ }^{11}$ The main influence, however, for Beddoes's choosing Hotwells was probably the presence of the Irish landowner and educational writer Richard Edgeworth

John Stock, Memoirs of T. Beddoes, M.D., with an analytical account of his writings (London: John Murray, 1811); Dorothy Stansfield, Thomas Beddoes M.D., 1760-1808: Chemist, physician, democrat (Dordrecht: Reidel, 1984).

$7 \quad$ Kenneth Johnston, Unusual Suspects: Pitt's reign of alarm and the lost generation of the 179os (Oxford: Oxford University Press, 2013) devoted an entire chapter (96-110) to Beddoes. See also Trevor H. Levere, "Dr. Thomas Beddoes at Oxford: Radical politics in 17881793 and the fate of the Regius Chair in Chemistry," Ambix 28 (1981): 61-9.

8 Thomas Beddoes to Davies Giddy, 7 April 1793, CRO MS DG/41/2, told him to send his next letter to Hope Square.

9 Phyllis Hembry, The English Spa 1560-1815: A social history (London: Athlone, 1990), 245-50.

10 James Watt sr. to Joseph Black, 17 July 1793, in R.G.W. Anderson and Jean Jones, eds., The Correspondence of Joseph Black, 2 vols. (Farnham: Ashgate, 2012), vol. 2, 703.

11 See Jan Ingen-Housz to Thomas Beddoes, 4 August 1794, quoted in Thomas Beddoes and James Watt, Considerations on the Medicinal Use of Factitious Airs, and on the manner of obtaining them in large quantities (parts 1 and 2, London: Johnson, [1794]), part 1, 31. Beale and Beale, Ingen Housz, pp. 452-4, 481-3 (see note 1). 
(1744-1817), whom he knew via his links with the Midlands industrialists. Edgeworth had been living in Clifton (north of Hotwells) with his third wife and large family since late 1791 for the sake of of his son's health. Beddoes regarded Edgeworth as being in "the highest rank of the untitled Aristocracy" (again suggesting Beddoes's concern with status and position). ${ }^{12}$ Furthermore, Beddoes had fallen in love with Edgeworth's daughter, Anna Edgeworth (17731824); they married in Ireland on 17 April $1794 \cdot{ }^{13}$ Approving the match, Edgeworth described his future son-in-law as "a little fat Democrat of considerable abilities" and thought that if he concentrated on medicine he would make his fortune. ${ }^{14}$ Beddoes did indeed build up a considerable and lucrative medical practice in the ensuing years. ${ }^{15}$

But Beddoes also spent much time developing his ideas about the possible therapeutic value of pneumatic chemistry, first mooted while still at Oxford. ${ }^{16}$ In the preceding decades Priestley, Cavendish and others had discovered various new airs, elastic fluids or gases, and Beddoes wanted to determine whether they could be used to cure diseases (particularly consumption) or at least mitigate them. Knowledge about Beddoes's work, especially its significance if successful, circulated fairly widely and attracted considerable attention including from no less a figure than the Whig grandee Georgiana Cavendish, Duchess of Devonshire (1757-1806), wife of the fifth Duke of Devonshire (1748-1811). She twice visited Beddoes in Hotwells, once just before Christmas 1793 and again in mid-January, evincing a strong interest in his ideas. ${ }^{17}$ On both occasions Beddoes demonstrated to her that if animals such as dogs or rabbits breathed oxygen beforehand they could survive freezing or emersion in nitrogen. ${ }^{18}$

Thomas Beddoes to Davies Giddy, 25 or 26 May 1793, CRO MS DG/41/21. A misreading of this passage may be the source of the mistake in Jay, Atmosphere, pp. 80, 289 (see note 3), in incorrectly awarding a knighthood to Edgeworth.

13 Thomas Beddoes to Davies Giddy, 25 or 26 May 1793, CRO MS DG/41/27, referred to becoming intimately acquainted with her during the previous three months.

Postscript by Edgeworth in Maria Edgeworth to Margaret Ruxton, 21 July 1793, National Library of Ireland MS 10166/7/105. Jay, Atmosphere, p. 91 (see note 3), suggested that Beddoes was not a gentleman, being "a tanner's son," and therefore there were class issues that required resolution before the marriage could take place. It is not clear on what basis Jay thought that Edgeworth would not have viewed an Oxford educated physician as anything other than a gentleman.

Thomas Beddoes to James Watt sr., 30 May 1797, LoB Ms 3219/4/29/14.

16 Thomas Beddoes to Davies Giddy, 2 March 1795, CRO DG/42/35.

17 Duchess of Devonshire to Dowager Countess Spencer, 1 January 1794 and 16 January 1794, Chatsworth MS CS5/1201 and 1204 respectively. don мs св/1/3/278; Duchess of Devonshire to Joseph Banks, 1 December 1794, in Neil 
It was not a coincidence that, following these aristocratic visits, Beddoes began to develop plans for a pneumatic hospital. This idea appeared first in a letter to the chemist Joseph Black, written on Christmas Eve $1793 \cdot{ }^{19}$ In another letter written to an unidentified correspondent "immediately" after Devonshire's second visit, Beddoes wrote: "it would be more practical to determine the medical effects of elastic fluids in one year, if we had six to twelve patients in a house with apparatus, than in twelve years of private practice." He estimated that such a hospital dedicated solely to this area of research could be established with six or seven hundred pounds, though he soon revised this to "not less than $£_{3000}$ \& not more than $£_{5000 . "}{ }^{20}$ In a folded broadsheet entitled A proposal towards the improvement of Medicine, printed at the end of July 1794, Beddoes argued that he had "abundantly proved, that the application of elastic fluids to the cure of diseases, is both practical and promising." He continued that a funded "Medical Pneumatic Institution" would much more effectively establish the benefits or otherwise of pneumatic medicine than "twenty years of private practice." A successful MPI, Beddoes argued, “ought to render itself useless, by so far simplifying methods and ascertaining facts, that every practitioner of medicine, at least, may both know how to procure and how to apply the different elastic fluids." If unsuccessful, then at least it had been tried. He thought such an institution should be able to settle the matter after operating for two or three years. Money would be required to rent a building accommodating a dozen patients, apparatus, furniture, a medical superintendent to run the institution, three servants, contingent expenses and medicines. ${ }^{21}$ Beddoes clearly understood a laboratory's material and staffing requirements, although not necessarily how they fitted together.

For nearly four years, from the autumn of 1794 until the summer of 1798 , Beddoes worked with his major supporters, including Devonshire, James Watt jr. (1769-1848), Tom Wedgwood (1771-1805) and Erasmus Darwin (1731-1802), undertaking a public fundraising campaign. In the end around 200 donors subscribed just over $£ 2000$, significantly below the minimum sum that Beddoes

Chambers, ed., The Scientific Correspondence of Joseph Banks, 6 vols. (London: Pickering, 2007), vol. 4, 1290.

19 Thomas Beddoes to Joseph Black, 24 December 1793, Black Correspondence, vol. 2, p. 724 (see note 10).

20 Thomas Beddoes to unidentified correspondent, mid-January 1794, in Stock, Beddoes, pp. 100-1 (see note 6). Thomas Beddoes to Thomas Wedgwood, mid-March 1794, wM MS MC 35. This letter is dated on the basis that Beddoes mentioned that he was about to go to Ireland.

Thomas Beddoes, A proposal towards the improvement of Medicine (Bristol: np, 1794). 
believed necessary. ${ }^{22}$ Nearly a third of this money came from just nineteen donations greater than $£_{20}$ (mostly from members of the Devonshire circle including seven aristocrats). Additionally, Wedgwood gifted $£_{500}$ and Beddoes's deceased patient William Lambton (1764-1797) bequeathed $£_{300}$. The reason why the general public appeal failed to raise the required amount, thus forcing Beddoes to rely heavily on his wealthy and aristocratic supporters, was due to his radical political views, which told against him. For example, despite her best efforts, the Dutchess of Devonshire (who disliked Beddoes's politics) could not obtain the support of the President of the Royal Society of London, Joseph Banks (1743-1820). ${ }^{23}$ He regarded Beddoes's opposition "to the present arrangement of the order of Society in this Country" as disqualifying him from support. ${ }^{24}$ Even Beddoes's strong supporters became frustrated with him; James Watt sr. told him that his political activities "will do more hurt to Pneumatics than you can possibly do good to the nation - amend your ways."25

During 1797 Beddoes and some subscribers became convinced that sufficient funds had been raised to ensure the practicality of imminently establishing the MPI. Discussions began about its possible location (some were not convinced of Bristol's appropriateness) and to search for a suitable superintendent. ${ }^{26}$ So far as the latter was concerned, Beddoes noted in October, that despite "many applications" none were suitable, which "disappointed" him. ${ }^{27}$ However, whilst staying in Penzance during the winter of $1797 / 8$ for the sake of their health, Wedgwood and Watt's son from his second marriage, Gregory Watt (1777-1804), had formed a friendship with an apprentice apothecary, the nineteen-year-old Humphry Davy.

22 This is detailed in Frank A.J.L. James, 'The first example ... of an extensive scheme of pure scientific medical investigation': Thomas Beddoes and the Medical Pneumatic Institution in Bristol, 1794 to 1799 (London: Royal Society of Chemistry Historical Group Occasional Publication, 2016).

23 Duchess of Devonshire to Earl Spencer, 30 May 1796, British Library Ms add 75923 (no foliation).

24 Joseph Banks to Duchess of Devonshire, 30 November 1794, Natural History Museum Dawson Turner Collection, 9, f. 125 .

25 James Watt sr. to Thomas Beddoes, 28 November 1795, LoB MS 3219/4/124/414.

26 Thomas Beddoes to James Watt sr., 26 May 1797, LoB MS 3219/4/29/13.

27 Thomas Beddoes to Thomas Girdlestone, 25 July 1797, private possession; Thomas Beddoes to James Watt sr., 24 October 1797, LoB MS 3219/4/29/23. 


\section{Humphry Davy}

Davy was born in Penzance in 1778, the eldest of five children. Many anecdotes testify to his being a bright child and after attending local schools he studied at Truro Grammar School in $1793 .{ }^{28}$ Leaving serious debts due to unwise mining investments, his father died in December 1794, a week before Davy's sixteenth birthday. To help overcome the family's financial problems, his mother, Grace Davy (1752-1826), apprenticed him to the Penzance surgeon and apothecary John Borlase (1753-1813). ${ }^{29}$ She also opened a milliners shop and took in lodgers, including at the end of 1797 Gregory Watt to whom Davy became close. Wedgwood, also in Penzance, and Watt were both interested in chemistry and it is from this time that Davy began his chemical studies - hitherto he had been more interested in poetry. ${ }^{30}$ Despite the existence of a 1790 English translation he read, amongst other texts, Lavoisier's Traité élémentaire de chimie (1789; second edition, 1793) in French, which he had learned from an émigré, and undertook some chemical experiments. ${ }^{31}$ All this brought him to the attention of Beddoes's former student and minor member of the Cornish gentry, Davies Giddy (1767-1839). His support secured Davy access to the well-equipped laboratory in Riviere House, Hayle, owned by John Edwards (1731-1807), manager of the Cornish Copper Company. ${ }^{32}$ Either there or possibly through an instrument maker in Penzance, Davy conducted experiments with an air pump demonstrating that a flintlock fired in a vacuum did not, contra Lavoisier, produce light. Furthermore, he also experimented on rubbing ice pieces together, from which he concluded that heat was a mode of motion rather than a fluid, a result he appears to have reached before hearing about the similar theory proposed around the same time by Benjamin Thompson, Count Rumford $\left(1753^{-1814}\right) \cdot{ }^{33}$

28 John Paris, The Life of Sir Humphry Davy, 2 vols. (London: Colburn and Bentley, 1831); John Davy, Memoirs of the Life of Sir Humphry Davy, Bart, 2 vols. (London: Longman, 1836).

29 Davy's indenture of apprenticeship in RI MS HD/5/3.

30 Wahida Amin, "The Poetry and Science of Humphry Davy," PhD thesis, University of Salford, 2013; Sharon Ruston, "From "The Life of the Spinosist" to "Life": Humphry Davy, Chemist and Poet," Margaret Hagen and Margery Skagen, eds., Literature and Chemistry: Elective affinities (Aarhus: Aarhus University Press, 2013), 77-97.

31 Davy, Davy, vol. 1, p. 21 (see note 28).

32 Paris, Davy, vol. 1, p. 47 (see note 28). W.H. Pascoe, ccc: The history of the Cornish Copper Company (Hayle: Haylebooks, 1981), 158.

33 Rumford, "An Inquiry concerning the Source of the Heat which is Excited by Friction," Philosophical Transactions 88 (1798): 80-102. 
Giddy suggested to Davy that he should send an account of his experiments to Beddoes which he did in April 1798, and which Beddoes later published. ${ }^{34}$ In July Beddoes wrote to Watt sr. asking for his opinion about appointing Davy ("concerning whom apply to Gregory") to be superintendent, to which he presumably consented. ${ }^{35}$ On 1 October, after extended negotiations, Borlase canceled the final sixteen and a half months of Davy's apprenticeship. Leaving Penzance the following day, Davy arrived in Bristol five days later. Beddoes had just moved into a large house in Rodney Place, commenting that the "houses in it are the best at Clifton \& I have bought the best". ${ }^{36}$ But, "above all," Davy told his mother soon after arriving, Rodney Place possessed "an excellent laboratory." 37 Davy did not disappoint and Beddoes reacted to him as did everyone else who met him at this time. In The Monthly Magazine, Beddoes described Davy as "A young man, endowed with talents for experimental researches at least equal to any person I have ever known." His patient, the poet Robert Southey (17741843), wrote, "We have an extraordinary young man lately settled here."38

Beddoes entrusted Davy with the task of spending the money that he had taken so long to raise and arranged for him to meet some of the MPI's major subscribers. For instance, Davy quickly visited the Midlands to see Watt sr. and his fellow industrialist James Keir (1735-1820). During this period Davy also began negotiations to acquire a building for the MPI in Dowry Square. ${ }^{39}$ In March 1799 The Bristol Gazette carried an advertisement announcing the opening there of the "New Medical Institution" which would be attended, presumably daily, by Beddoes and Davy between 11am and 1pm. ${ }^{40}$ Shortly afterwards, Davy drafted a "Prospectus" for the MPI (though it is not clear if this was ever printed) in which he wrote that "upwards of forty are become outpatients [at the MPI] within this fortnight \& we could immediately fill the house with in-patients." ${ }^{41}$ The following month the number of out-patients had

34 Thomas Beddoes to Davies Giddy, 14 April 1798, CRO DG/42/2. Humphry Davy, "An Essay on Heat, Light, and the Combinations of Light," Thomas Beddoes, ed., Contributions to physical and medical knowledge, principally from the West of England (London: Longman, 1799), 5-147.

35 Thomas Beddoes to James Watt sr., 15 July 1798, LoB MS 3219/4/29/32.

36 Thomas Beddoes to James Watt jr., October 1798, LoB MS 3219/6/2/B/72.

37 Humphry Davy to Grace Davy, 11 October 1798, RI MS HD/26/A/1.

38 The Monthly Magazine 6 (1798): 238. Robert Southey to William Taylor, 24 February 1799.

39 Humphry Davy to Grace Davy, 11 October 1798, RI MS HD/26/A/1.

$40 \quad$ The Bristol Gazette (21 March 1799): $3 \mathrm{c}$.

41 Humphry Davy, "Prospectus of the design of the Institution," [late March / early April 1799], RI MS HD/20/B, 11-16, quotation on 14. 
increased to eighty. ${ }^{42}$ By November, there were five lady in-patients being subjected to Beddoes's novel treatment of inhaling the breath of an Alderney cow. ${ }^{43}$

Following the MPI's opening, Davy began experimentation on dephlogisticated nitrous air as Priestley, its discoverer, had named it, or nitrous phosoxyd as Davy initially termed it before finally calling it, following the new nomenclature developed by Lavoisier and his associates, nitrous oxide. He discovered the gas's pleasurable physiological action and self-experimented by frequently inhaling it in large quantities - on one occasion sixteen quarts (just over eighteen liters).$^{44}$ This sustained exposure to the gas so damaged his health that he spent most of November 1799 in Cornwall, where he suffered withdrawal symptoms. After thirty-three days without the gas, he inhaled nine quarts on his return. ${ }^{45}$ In his first book, Researches, Chemical and Philosophical; Chiefly Concerning Nitrous Oxide, or Dephlogisticated Nitrous Air, and its Respiration, Davy described the results of his own experimentation and the accounts of many of those in Beddoes's Bristol circle whom he persuaded to inhale. ${ }^{46}$ Published mid-180o, Researches cost half a guinea and ran to nearly six hundred pages. He divided the text roughly equally between providing a detailed chemical analysis of the gas and describing its physiological properties. Towards the end, and then only very briefly, did Davy make reference to any possible therapeutic use, though Beddoes thought there might be. ${ }^{47}$ As countless writers have pointed out, Davy did not observe the anaesthetic property of nitrous oxide. ${ }^{48}$

Despite Beddoes's avowed aims for the MPI, for which subscriptions had been so painfully obtained, Davy, somewhat subversively, developed and pursued a rather different research agenda. In this Davy exhibited a pattern of behavior similar to those of aristocratic laboratories where the researchers followed their own interests. (What direct knowledge he might have had of them

42 Humphry Davy to Davies Giddy, 18? April 1799, Paris, Davy, 1: pp. 79-82 (see note 28). Paris dated this letter 10 April 1799, but such a date contradicts other evidence. Davy's numbers can, on occasion, be confused. Thomas Frankland to James Smith, 18 November 1799, Linnean Society MS JEs/COR/15/6.

44 Humphry Davy to Davies Giddy, 18? April 1799, Paris, Dary, vol.1, pp. 79-82 (see note 28).

45 Humphry Davy, Researches, Chemical and Philosophical; Chiefly concerning nitrous oxide, or dephlogisticated nitrous air, and its respiration (London: Johnson, 1800), 478.

46 Ibid.

47 Thomas Beddoes, Notice of Some Observations Made at the Medical Pneumatic Institution (London: Longman, 1799).

48 Jan Golinski, "Humphry Davy: The experimental self," Eighteenth-Century Studies 45 (2011): 15-28, especially 18-19. 
is not known, but he later developed a taste for staying in large aristocratic country houses.) Despite Beddoes's clear aims for the MPI, he had not found a way of ensuring that they would be fulfilled, suggesting that he had not considered how research in a laboratory should be managed or guided towards a defined aim. Alternatively Beddoes may have recognized that he had too many other commitments and interests and so gave Davy a free hand, which also illustrates similarities to aristocratic laboratories.

A similar pattern occurred when news reached Davy, just as he was completing his Researches, of an invention made by Alessandro Volta (1745-1827), which he called a pile producing galvanic electricity, but which Davy would shortly rename the battery. ${ }^{49}$ Davy included a very brief reference to Volta right at the end of his Researches and Beddoes arranged for a pile to be built. ${ }^{50}$ For the remainder of the year Davy experimented on galvanism, recording this research in two notebooks, beginning in August, and in a series of papers published monthly (apart from January) in A Journal of Natural Philosophy, Chemistry and the Arts from September 1800 through to February $1801 .^{51} \mathrm{In}$ these papers Davy announced, amongst other discoveries, that electricity would pass through organic tissue, that charcoal could be used as an electric pole and came to the overall conclusion, contra Volta, that "Galvanism ... [was] a process purely chemical." ${ }^{2}$ Such conclusions confirmed Davy's view, probably written in his notebook during mid-1799, that "Chemistry must no longer [be] considered as a science important because it is connected with our artificial wants; but because it promises to unfold to us the laws of our own existence."53 Right from the start, Davy believed studying galvanism would "acquaint us with some of the laws of life!," a view stemming ultimately from the origin of galvanism in animal electricity. ${ }^{54}$ Once again Davy displayed little concern for whether his work had any therapeutic value or relevance to the MPI.

49 Humphry Davy, "An Account of some Galvanic Combinations, formed by the Arrangements of single metallic Plates and Fluids, analogous to the new Galvanic Apparatus of Mr. Volta," Philosophical Transactions 91 (1801): 397-402, 400.

50 Davy, Researches, p. 568 (see note 45). A Journal of Natural Philosophy, Chemistry and the Arts 4 (1800): 275. RI MS HD/20/C and /22/B. Papers listed in June Fullmer, Sir Humphry Dary's Published Work (Cambridge, MA: Harvard University Press, 1969).

$5^{2}$ Humphry Davy to Davies Giddy, 20 October 180o, private possession, but also Paris, Davy, vol. 1, pp. 108-11 (see note 28).

53 RI MS HD/20/A, p. 266.

54 Humphry Davy to Davies Giddy, 3 July 180o, Paris, Dary, vol. 1, pp. 85-8 (see note 28). 
Beddoes, who also thought they were close to understanding living systems, sought to take advantage of Davy's straying, by arguing that to exploit his work (and thus continue pursuing the MPI's stated aims) would require "the most extensive application of chemistry to physiology" ${ }^{\prime 55}$ To achieve this he would need to appoint an expert anatomist as well as an instrument maker and establish a manufactory on the scale of Boulton and Watt's recently completed foundry for constructing steam engines at Soho, then one of the largest industrial facilities in the world. ${ }^{56}$ Beddoes pointed out, somewhat unnecessarily, that additional funding would be required ${ }^{57}$ One does have to wonder how far Beddoes, or indeed anyone else, believed his unrealistic rhetoric bordering on fantasy. He essentially used the success of Davy's discovery to make a case for significant extra financial support for the MPI. In this he saw Davy as a valuable resource, writing that he considered that the effect of his presence "as more than virtually doubling the fund." 58

Despite his value to Beddoes, Davy realized that he had major problems with his career due to "the political odium attached to its [the MPI's] founder."59 Owing to the non-survival of papers detailing the MPI's operation, we have no knowledge of its expenditure pattern, only that Davy earned £200 annually. 60 With only finite resources, it would have been apparent to him that the MPI's duration would be limited - as Beddoes had originally intended in his 1794 Proposal. Davy's continuing connection with a known political radical would be an increasing liability in finding a new job, so perhaps it is not too surprizing that about two years after his arrival in Bristol, he began considering his future prospects. In two letters written in September and November 180o, he hinted to his mother that he was looking for alternative employment. ${ }^{61}$ In the latter month writing from Lisbon, Southey opined that "Davy will not always remain at the Pneumatic Institution." ${ }^{\prime 2}$ Though it is not clear what options might then have been open to him, by early January he had started negotiations to move to the RIGB in London. ${ }^{63}$

\footnotetext{
55 Beddoes, Notice, p. 34 (see note 47).

56 Peter Jones, Industrial Enlightenment: Science, technology and culture in Birmingham and the West Midlands, 1760-1820 (Manchester: Manchester University Press, 2008), 55.

57 Beddoes, Notice, pp. 35-6 (see note 47).

58 Ibid., p. 6.

59 Humphry Davy to John Tonkin, 12 January 1801, Davy, Davy, vol. 1, pp. 107-9 (see note 28).

60 Humphry Davy to Grace Davy, 19 January 1799, RI MS HD/26/A/2.

61 Humphry Davy to Grace Davy, 27 September 180o, SM MS 333/2 and 19 November 1800, Davy, Davy, vol. 1, pp. 105-7 (see note 28).

62 Robert Southey to William Taylor, 26 November 1800.

63 Humphry Davy to Grace Davy, 31 January 1801, SM MS 333/4.
} 


\section{The Royal Institution of Great Britain}

At a meeting held on 7 March 1799 in Joseph Banks's Soho Square house, fiftyeight men (around a quarter of whom were aristocrats), each pledged fifty guineas, a substantial sum, to become Proprietors of a new "Institution for Diffusing the Knowledge and Facilitating the General Introduction of Useful Mechanical Inventions and Improvements, and for Teaching, By Courses of Philosophical Lectures and Experiments, the Application of Science to the Common Purposes of Life." 64 They also elected a committee of Managers charged with establishing and then running the new institution. ${ }^{65}$ In addition to Banks and Rumford, a third of this committee were aristocrats and in May George Finch, ninth Earl of Winchilsea (1752-1826) became President. The RIG B founders' original intention was to communicate scientific knowledge to its Proprietors, all of whom came from the wealthy echelons of society, as well as Life and Annual Subscribers who contributed ten and two guineas respectively. To deliver its program the RIGB needed a building and mid-1799 it moved into 21 Albemarle Street, off Piccadilly. This had been a gentleman's townhouse, built during the eighteenth century, and thus needed conversion to house a scientific institution that included a well-equipped laboratory in which to prepare lecture demonstrations. ${ }^{66}$ Rumford was charged with overseeing the necessary work and, just a year after its foundation, a temporary lecture room had been constructed. The first lecture in a course on various natural philosophical and chemical topics was delivered on 11 March 1800 by Thomas Garnett (1766-1802) ${ }^{67}$ He had enjoyed a reasonably successful career as an itinerant lecturer during the latter part of the eighteenth century, but immediately before moving to the RIGB had been employed to lecture at the Andersonian Institution in Glasgow.

In April 1800 the Managers authorized the construction of a large lecture theater at the building's northern end, aiming for its completion by the start of

64 Proposals for forming by subscription, in the Metropolis of the British Empire, a Public Institution for Diffusing the Knowledge and Facilitating the General Introduction of Useful Mechanical Inventions and Improvements, and for Teaching, By Courses of Philosophical Lectures and Experiments, the Application of Science to the Common Purposes of Life ([London: np, 1799]), 43.

$65 \quad$ RI MM, 9 March 1799, 1: 1.

66 Frank A.J.L. James and Anthony Peers, "Constructing Space for Science at the Royal Institution of Great Britain," Physics in Perspective 9 (2007): 130-85.

67 Gentleman's Magazine, $70(1)$ (1800): 382. For the content see Journals of the Royal Institution of Great Britain 1 (5 April 180o): 15-16. Note this text was omitted from volume 1 of the bound edition of the Journals. 
1801. ${ }^{68}$ They contracted with the Pimlico builder Thomas Hancock to undertake the extensive work involved which meant that the building became unusable until the theater was completed. ${ }^{69}$ This prompted the Managers (based on Banks's proposal) to dismiss five servants, including the lecture assistant, a decision that did not commend itself to Garnett who thought that the RIGB should have a permanent assistant. ${ }^{70}$ The project overran and, at their meeting in early February 1801, the Managers decided that the second season of lectures would commence when the lecture theater was completed. Furthermore, they agreed that Banks, Rumford and Cavendish (now a Manager) would form a committee to supervise the preparation of the syllabi and that none should be published without their authorisation..$^{71}$ The reason for this latter decision was Garnett's imminent publication of the Outlines of his courses both on chemistry and on natural and experimental philosophy.72 Indeed the prefaces (where he stated the times that he would be delivering the lectures) were both dated 2 February, though the chemistry volume did not appear until mid-March. ${ }^{73}$ Garnett, behaving as one might expect of a former itinerant lecturer, published these without the Managers' permission, suggesting a lack of skill on their part about how to manage an experienced lecturer. Two weeks later they ordered that copies of the minutes recording their decisions made on 2 February should be sent to him. ${ }^{74}$ He thus began his second season under something of a cloud so far as his employers were concerned. Furthermore, Garnett had written to Rumford requesting an increase in salary in accordance with what he believed were the terms of his original appointment. ${ }^{75}$ The Managers deferred making a decision until the annual accounts

68 RI MM, 14 April 180o, 2: 56. Rumford to Marc-Auguste Pictet, 5 July 180o, David Bickerton and René Sigrist, eds., Marc-Auguste Pictet 1752-1825 Correspondance sciences et techniques tome III: Les correspondants britanniques (Geneva: Slatkine, 2000), 558-9.

69 RI MS RI $/ 1 / G / G / 1$.

70 RI MM, 12 June 1800, 2: 104. Rumford had proposed earlier in the day that Banks did this. Rumford to Joseph Banks, 12 June 180o, Banks' Scientific Correspondence, vol. 5, p. 1560 (see note 18). Thomas Garnett to Thomas Webster, 27 September 180o, Bence Jones, Royal Institution, pp. 172-4 (see note 3 ).

$71 \quad$ RI MM, 2 February 1801, 2: 126-7.

72 Thomas Garnett, Outlines of a Course of Lectures on Chemistry (London: Cadell and Davies, 1801) and Outlines of a Course of Lectures on Natural and Experimental Philosophy: Delivered at the Royal Institution of Great Britain (London: Cadell and Davies, 1801).

74 RI MM, 16 February 1801, 2: 134.

75 Thomas Garnett to Rumford, 22 February 1801, copied in RI MM, 23 February 1801, 2: 136-8. 
had been prepared and the RIGB's financial position ascertained. ${ }^{76}$ When Garnett again pressed his case in mid-May, a specially convened Managers' meeting, held on the 25th refused the increase; Garnett's subsequent resignation offer was accepted. 77

It is possible that as early as their meeting held on 5 January 1801 , the deteriorating relations between Garnett and the RIGB may have prompted the Managers to ask Rumford to seek a replacement. ${ }^{78}$ Rumford had spent much of the previous September and October in Edinburgh with Black's successor at the University, Thomas Hope (1766-1844). He had known Beddoes when they were students there and, having visited the MPI at some point during 1800 , sung Davy's praises to Rumford. ${ }^{79}$ Around 10 January, Rumford must have approached Davy, offering him by the end of the month, that should he move to the RIGB he would shortly become the "sole Professor of Chemistry." 80 Davy visited London during mid-February where he met Rumford, Banks and Cavendish. ${ }^{81}$ These meetings resulted in the Managers appointing Davy "Assistant Lecturer in Chemistry, Director of the Chemical Laboratory, and Assistant Editor of the Journals of the Institution" on 16 February at an annual salary of 100 guineas plus accommodation. ${ }^{82}$ This seems to represent a diminution in income, suggesting some keenness on Davy's part to leave Bristol. The same day Rumford wrote Davy's appointment letter in which he copied the Managers' minutes, adding, what was not noted there, their additional agreement that, provided he proved his fitness, he would be appointed Professor of Chemistry in the next two or three years with an annual salary of $£_{300 .}{ }^{83}$ That promise would make up for any immediate financial loss and Davy returned to Bristol, probably for a couple of weeks, to settle his affairs. Beddoes, despite his

76 RI MM, 23 February 1801, 2: 138.

77 RI MM, 25 May 1801, 2: 180. RI MM, 15 June 1801, 2: 189-9o.

78 Paris, Davy, vol. 1, p. 115 (see note 28), based on an account written thirty years later; there is no reference to such authorisation in RI MM, 5 January 1801, 2: 118-21.

79 Humphry Davy to Thomas Hope, 28 June 1801, transcript in RI MS HD/28/D/38. Humphry Davy to John Tokin, 12 January 1801, Davy, Davy, vol. 1, pp.107-9 (see note 28). Thomas Traill, "Memoir of Dr Thomas Charles Hope, late Professor of Chemistry in the University of Edinburgh," Transactions of the Royal Society of Edinburgh 16 (1848): 419-34, 432.

8o Humphry Davy to Grace Davy, 31 January 1801, SM MS 333/4, noted that he had been in discussions with the RIGB for three weeks.

81 Humphry Davy to Davies Giddy, 8 March 1801, Paris, Davy, 1: pp. 116-9 (see note 28).

82 RI MM, 16 February 1801, 2: 134.

83 Rumford to Davy, 16 February 1801, Bence Jones, Royal Institution, pp. 317-9 (see note 3). Davy was appointed Professor the following year, RI MM, 31 May 1802, 3: 43. 
view of Davy's key role in the MPI, approved his move to London "with great liberality." ${ }^{84}$ On Wednesday 11 March 1801 Davy returned to the RIGB to commence the next stage of his career. ${ }^{85}$

At the RIG B Davy, despite no previous experience, very quickly established himself as an immensely attractive and engaging lecturer. Possibly his not having any previous experience as an itinerant lecturer meant that he could, unlike Garnett, conform more easily to the Managers' expectations. His initial two courses illustrated his immediate impact. The first starting on 25 April 1801 were evening lectures, while the second was an afternoon series "attended not only by men of science but by numbers of people of rank and fashion." 86 The pharmaceutical chemist William Allen (1770-1843) recorded in his diary the success of Davy's first lecture, describing it as "A most capital one. He bids fair to rise high in the philosophical world," a view shared by the writer in the Philosophical Magazine, who noted Banks's presence in the audience. ${ }^{87}$ Davy's course on pneumatic chemistry concluded on 20 June with a lecture attended by nearly 500 people, which included a practical demonstration of nitrous oxide's physiological effects. ${ }^{88}$ Davy was as nearly carried away with his own success as a lecturer, as anyone who had come under the influence of nitrous oxide: "I have been nobly treated by the managers, God bless us I am about 1.000.00o times as much a being of my own volition as at Bristol. My time is too much at my own disposal - So much for egotism - for weak glorious, pitiful, sublime, conceited egotism." 89 He would retain the RIGB's fashionable audience until his retirement in 1812 (at the age of thirty-three) on marriage to a widow - a wealthy heiress who had attended his 1811 lectures. ${ }^{90}$

During June 1801, the Managers, presumably led by Rumford, and possibly mindful that Davy was being left too much to his own volition, proposed, in line with the RIGB's utilitarian strand, that Davy should "examine the state of the arts and to begin with the process of tanning" during the autumn. ${ }^{91}$ By the end of the month Davy had agreed to deliver a course on tanning during

84 Humphry Davy to Davies Giddy, 8 March 1801, Paris, Davy, vol. 1, pp. 116-9 (see note 28).

85 RI MM, 16 March 1801, 2: 150-1.

86 "Royal Institution of Great Britain," Philosophical Magazine 10 (1801): 86-7, 86.

87 Life of William Allen, with selections from his Correspondence, 3 vols. (London: Gilpin, 18467), vol. 1, 54 (entry for 25 April 1801). "Royal Institute [sic] of Great Britain," Philosophical Magazine 9 (1801): 281-2.

88 Humphry Davy to John King, 22 June 1801, Bristol Record Office, 32688/31. "Royal Institution of Great Britain," Philosophical Magazine 10 (1801): 86-7, 86.

89 Humphry Davy to John King, 22 June 1801, Bristol Record Office, 32688/31.

$90 \quad$ RI MM, 28 January 1811, 5: 178.

91 Thomas Poole to Josiah Wedgwood jr., 25 and 26 June 1801, WM MS MC 55. 
November, but in exchange received three months leave, starting in July, "for the purpose of making himself more intimately acquainted with the practical part of the business of tanning." Furthermore, Davy was also "instructed" to prepare lectures for delivery in December on dying, staining and printing various cloths. ${ }^{92}$ None of these lectures were ever delivered. This suggests that because of his success attracting audiences to the RIGв Davy could subvert the Managers' intentions without, unlike Garnett, suffering any penalty. Nevertheless, in his famous 1802 lecture Discourse Introductory to a Course of Lectures on Chemistry Davy went out of his way to emphasise the utilitarian value of chemistry.

At this time Davy's most significant contribution to utilitarian chemistry was his appointment, at Banks's instigation, as Professor of Chemistry to the Board of Agriculture. Until retirement he delivered annually a successful series of six lectures on agricultural chemistry to the Board. ${ }^{93}$ Furthermore, despite the proposal in May 1805 that the Board should possess its own laboratory in its Sackville Street building, it was eventually agreed that the RIGB's laboratory would undertake this function. This had been facilitated earlier in the year by the Managers appointing Davy Director of the Laboratory and specifying its public remit. ${ }^{94}$ This gave Davy the authority to undertake "analysis of such Substances as ... the Professor of Chemistry shall deem of Scientific or Public Importance. ${ }^{95}$ This new function took material form when Davy began a formal laboratory notebook in October. Following his death the Royal Institution had to apply to Davy's executors for the return of the first two of these notebooks which "had several years ago been taken away by Sir H Davy", illustrating his almost aristocratic sense of ownership of the laboratory. ${ }^{96}$

Davy did fulfill the RIGB's stated purposes to provide scientific lectures and practical scientific advice. But during his period there Davy de facto added scientific research to them, which had never been intended by the founders. It was the RIGB's well-equipped laboratory that allowed him also to continue the experimental work that he had started in Penzance and continued at the MPI. In particular he concentrated at the RIGB on electrical research, which formed the topic of his first paper read to the Royal Society of London in June $1801 .{ }^{97} \mathrm{In}$ the ensuing years he developed the first coherent theory of electro-chemical

$92 \quad$ RI MM, 29 June 1801, 2: 198.

93 Frank A.J.L. James, “'Agricultural Chymistry is at present in it's infancy”: The Board of Agriculture, The Royal Institution and Humphry Davy," Ambix 62 (2015): 363-85.

RI MM, 28 January 1805, 4: 17. The Managers seemed to have forgotten that this was part of Davy's original job title.

95 RI MM, 11 March 1805, 4: 40.

96 RI MS HD/6 and 7. RI MM, 2 October 1829, 7: 276; 7 December 1829, 7: 285.

97 Humphry Davy, "Galvanic Combinations." (see note 49). 
action, a term he coined. ${ }^{98}$ During his research Davy isolated for the first time a number of chemical elements such as sodium and potassium (which he so named). ${ }^{99}$ By turning the RIGB into a site of independent chemical research Davy fundamentally subverted the institution's founding intentions. The lecture program and providing scientific advice to the state continued, which financially supported the RIGB and thus Davy's research. And when that money became insufficient Davy also copied Beddoes's fund-raising practices in persuading the RIGB to organise a subscription to pay for a mineralogical collection and, towards the end of the decade, one to pay for a giant electric battery with which he could continue his electro-chemical researches. ${ }^{100}$

\section{Conclusion}

Beddoes asserted that the MPI was "perhaps, the first example, since the origin of civilsociety, of an extensive scheme of pure scientific medical investigation."101 One interpretation of this view is that Beddoes believed that the MPI broke with earlier models of laboratory organisation and in terms of funding this was probably so. However, initially both the MPI and also the RIGB were organisations, which possessed underdefined or unspecified features, as one might expect at the commencement of such novel projects. This allowed a great deal of space for unintended consequences and individual human agency, especially, as in Davy's case, where he had a clear idea that he wanted to pursue independent research. Davy's work in Bristol essentially continued his chemical career begun in Penzance. There using locally available resources Davy, under the influence and guidance of Giddy, Wedgwood and Gregory Watt, had developed his ability and enthusiasm for chemical theorizing and practical experimentation. Such skills were just what Beddoes needed, signified by his immediately praising Davy's experimental prowess. With his already existing experience Davy took full advantage of the resources that Beddoes provided in Bristol. Davy, single-handedly, thus made the MPI a success in areas other than

98 Humphry Davy, "The Bakerian Lecture, on some new Phenomena of chemical Changes produced by Electricity, particularly the Decomposition of the fixed Alkalies, and the Exhibition of the new substances which constitute their bases; and on the general Nature of alkaline Bodies," Philosophical Transactions 98 (1808): 1-44, 2.

99 Ibid., p. 32.

100 June Fullmer, "Humphry Davy: Fundraiser," Frank A.J.L. James, ed., The Development of the Laboratory: Essays on the place of experiment in industrial civilisation (London: Macmillan, 1989), 11-21.

101 Thomas Beddoes, Notice, p. 4 (see note 47). 
the intended one of determining the therapeutic value of gases. Left largely to his own devices, Davy made a significant medico-chemical discovery, published his first book and commenced electrical experimentation, which he clearly believed had further potential, especially in understanding life. But this was not what Beddoes had worked, or hoped, to establish, though he willingly sought to take advantage of Davy's discoveries. Beddoes seems not to have considered how laboratory research should be managed, but had let Davy behave in ways reminiscent of Priestley and Ingen-Housz at the aristocratic laboratory set up by the second Earl of Shelburne. That this lacuna can be attributed to Beddoes rather than Davy is apparent, since, following his departure for London, research at the MPI ceased and it soon turned instead into a more conventional hospital. ${ }^{102}$ The MPI did not develop into a sustainable institution and could not fully survive Davy's departure.

Davy's commitment to his own research and his experience in Penzance and Bristol allowed him to add research to the RIGB's original activities, a move that would have far reaching consequences. That Davy exerted such a profound impact in developing research at both the MPI and the RIGB, suggests that his existing skills and experience were crucial in shaping both those institutions. The RIGB, much better funded (though it had more than its fair share of financial crises) than the MPI, had significant and continuing support from many wealthy, aristocratic and influential individuals. But, as with the MPI, its roles and management had not been fully defined, which again provided Davy with the institutional opportunity and space to maneuver into place his own ideas about what the RIGB should do.

In some ways his influence at both the MPI and the RIGB was similar to those aristocrats who had built their own laboratories which came to an end with their deaths (or suspension of interest), in that he constructed for himself similar freedom to pursue his own interests at both institutions. But the RIGB's institutional stability was strong enough to survive his departure and it continued to attract and foster talented men for the remainder of the nineteenth and into the twentieth century. It was in such a manner that Davy's subversion illustrates how a successful research laboratory could be created and run in a society still dominated by aristocrats.

102 Mary E. Fissell, Patients, Power, and the Poor in Eighteenth Century Bristol (Cambridge, Cambridge University Press, 1991), 118-19. 


\section{Acknowledgments}

I am grateful to the participants of the "Situating Chemistry" workshops held in Leuven, Berlin, Florence and Haarlem for discussions on papers that I presented and particularly to Lissa Roberts for comments on this paper. I thank the following institutions for access to their manuscript collections: The Royal Institution (RI), The Library of Birmingham (LoB), the Cornwall Record Office (CRO), The Wedgwood Museum (wM), The Science Museum (sM), the British Library, the Royal Society of London, the National Library of Ireland, the Linnean Society, The Natural History Museum and Chatsworth. Letters written by Humphry Davy are freely available on-line at <www.davy-letters.org.uk $>$ as part of the project to publish them by the end of the decade. In the meantime this paper cites their archival or printed locations. Letters from Robert Southey are available at <https://www.rc.umd.edu/editions/southey_letters $>$ and are here cited by author, recipient and date. 